Dept. of Parasitology,

Faculty of Veterinary Medicine, Alfateh University.

\title{
PREVALENCE OF TOXOPLASMA GONDII ANTIBODIES IN LIBYAN SHEEP (FAT-TAILED BARBARY)
}

(With 2 Tables)

By

\section{K.M. EL-GOMATI; A.M. RASHED;A.S. ELNAAS and M.M. ELSAID*}

*Dept. of Parasitology, Faculty of Medical Technique, Alfateh University,

P.O. Box 13662-Tripoli-Libya.

(Received at 3/9/2008)
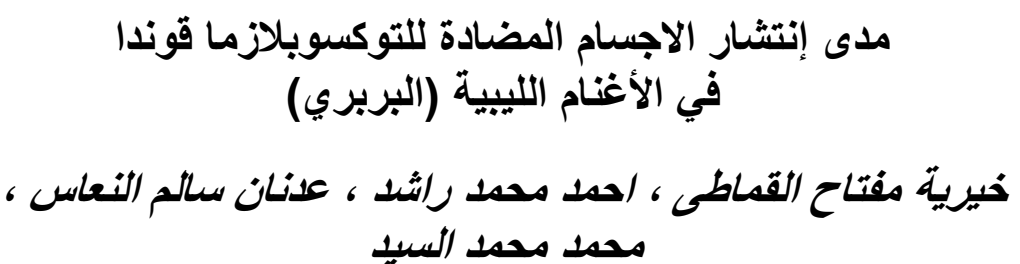

لقد شملت هده الدر اسة على 253 عينة من مصل الدم لفحص الأجسام المضادة لتعيين انتشار

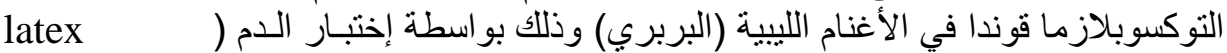

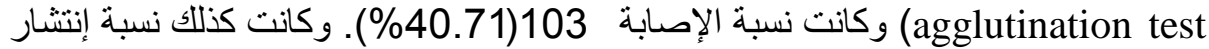

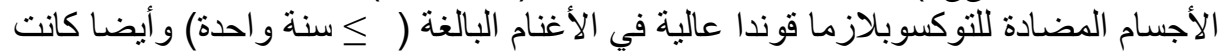

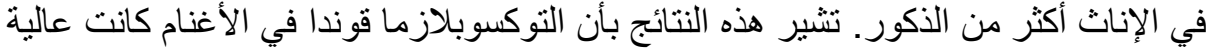
واسعة الانتشار في منطقة طر ابلس.

\section{SUMMARY}

This study was carried out in order to determine the prevalence of Toxoplasma gondii antibodies in Libyan sheep. A total of 253 sera taken from sheep were examined using a latex agglutination test. Out of 253 samples tested $103(40.71 \%)$ were determined as seropositive. The prevalence of Toxoplasma antibodies was higher in adult sheep ( $\geq 1$-year-old), and in female than male. These results indicate that ovine toxoplasmosis is widespread in Tripoli area.

Key words: Toxoplasma gondii, antibodies, Libyan sheep.

\section{INTRODUCTION}


Toxoplasma gondii is an obligatory intracellular protozoan parasite which appears to have broad host specificity. Cats and wild felines are the only definitive host while all other warm- blooded animals including human are intermediate hosts. Infection is acquired by ingestion of oocysts excreted by cats that contaminate food or water (Nissapatorn et al., 2004). Cysts formed in sheep and other animals are also sources of infection for human beings too (Tenter et al., 2000). Congenital transmission also occur when an uninfected mother acquires primary infection during pregnancy (Nissapatorn et al., 2004).

In human the disease is widespread and it is usually asymptomatic, but in some cases it is characterized by adenopathy, fever and fatigue, however it can have serious consequences in fetuses, neonates and in immunocompromised individuals (Nissapatorn et al., 2004).

Toxoplasma infection has a major economic impact on sheep resulting in prenatal deaths, abortion, fetal absorption and stillbirths (Masala et al., 2003).

The seroprevalence of toxoplasmosis in sheep has been reported in several parts around the world. The prevalence rates have been varied among countries and diagnostic methods used (Tenter et al., 2000) Latex agglutination test was used by several researchers for the detection of seroprevalence of Toxoplasma infection among sheep. (Sanad and Alohabban 2007, Oncel et al., 2005, Helmick et al., 2002, HashemiFesharki, 1996, Zaki, 1995, Hoghooghi-Rad and Afraa, 1993 and Trees et al., 1989)

Although human toxoplasmosis in Libya has been reported in Tripoli by Khadre and Elnageh (1987) and in Benghazi by Kassem and Morsy (1991) there is little available literature about its prevalence among sheep.

The aim of the present work was to carry out preliminary study to determine the prevalence of Toxoplasma gondii among Fat-tailed Barbary sheep in Tripoly, Libya

\section{MATERIALS and METHODS}

\section{Animals}

The present study included a total number of 253 sheep (Fattailed Barbary), of both sexes, coming from different regions and slaughtered in the abattoirs in city of Tripoli. The age of study group ranged from 6 months to 7years old. 


\section{Samples}

Blood was collected in tubes without anticoagulant directly from the jugular vein at the time of slaughtering. The samples were allowed to clot ( 2 hours), centrifuged at $3000 \mathrm{~g}$ for 5 minute and stored at $-20^{\circ} \mathrm{C}$ till testing.

\section{Serological testing}

Serum samples were tested using latex agglutination test (toxocell latex Spain) according to the procedure listed by the manufactured company. Allowing the reagents to reach room temperature, $50 \mathrm{ml}$ of the serum (or one drop of control) were placed on one section of the slide. After shaking the reagent vial one drop of reagent was added next to the drop of sample. Both drops were mixed with a stirrer till cover the whole surface of the slide section, the slide was then rotated for 5 minutes manually or on a rotary shaker set at 80$100 / \mathrm{rpm}$. Results were determined by the presence or absence of agglutination.

\section{RESULTS}

1- Out of 253 serum samples examined in this study a total of 103 $(40.71 \%)$ were found to be seropositive. The association of age with the presence of infection revealed that seroprevalence was the highest in $\geq 1$ year-old age group when compared with < 1year (Table 1)

Table1: Toxolasma gondii infection in relation to age.

\begin{tabular}{|l|c|c|c|c|c|}
\hline \multirow{2}{*}{ Age groups } & \multirow{2}{*}{$\begin{array}{c}\text { N0 of sheep } \\
\text { examined }\end{array}$} & \multicolumn{2}{|c|}{ Seropositive } & \multicolumn{2}{c|}{ Seronegative } \\
\cline { 3 - 6 } & & No & rate\% & No & rate\% \\
\hline 6mon-1year & 151 & 49 & 32.5 & 102 & 67.5 \\
\hline$\geq 1$ year & 102 & 54 & 52.9 & 48 & 47.1 \\
\hline Total & 253 & 103 & 40.7 & 150 & 59.3 \\
\hline
\end{tabular}

2 - A total of $63(49.2 \%)$ out of 128 females and a total of 40 (32.0\%) out of 125 males sheep tested were seropositive. Seroprevalence was the highest in females when compared with male as shown in Table 2.

Table 2: Toxoplasma gondii infection in relation to sex.

\begin{tabular}{|l|c|c|c|}
\hline sex & $\begin{array}{c}\text { No of examined } \\
\text { Shaon }\end{array}$ & Seropositive & seronegative \\
\hline
\end{tabular}




\begin{tabular}{|l|c|c|c|c|c|}
\hline & & No & rate\% & No & rate\% \\
\hline Female & 128 & 63 & 49.2 & 65 & 50.8 \\
\hline male & 125 & 40 & 32.0 & 85 & 68.0 \\
\hline Total & 253 & 103 & 40.7 & 150 & 59.3 \\
\hline
\end{tabular}

\section{DISCUSSION}

Toxoplasmosis is a zoonotic disease caused by Toxoplasma gondii and has been known in many countries since 1908 (Dubey and Beattie, 1988). Toxoplasma gondii in sheep is distributed world wide, with prevalence rates ranging up to $100 \%$ in different countries (Dubey and Beattie, 1988; Tenter et al., 2000).

The prevalence of $40,71 \%$ for Toxoplasma gondii antibodies found in this study is lower than those found in Ethiopia (56\%), Turkey $(65,08 \%)$ and Italy (77,8\%), (Negash et al., 2004, Oncel et al., 2005, Fusco, et al., 2007). On the other hand it is higher than those found in Bangladesh (17.65\%), Brazil (18.75\%), Iran (22.85\%), Tripoli $(13,5)$ and Morocco(27.6\%), (Samad, et al., 1993; Pita Gondim, et al., 1999; Zia Ali et al., 2007; Gusbi, 1986; Sawadogo et al., 2005)

The difference observed could be due to the sampling techniques husbandry methods used in the different regions, frequency of cats on farms. Also the climatic variation has a role in Toxoplasma distribution as the prevalence of toxoplasmosis is higher in warm, moist as compared to cold, dry ones. This is attributed to the longer viability of T. gondii oocysts in moist or humid environments (Dubey, 1994).

The present study showed elevation in the prevalence of Toxoplasma infection in sheep in Tripoli area (40.71\%) as compared with that done in the same area by the same technique by Gusbi (1986) $(13,5 \%)$, which may results on increase the risk of human infection.

In the present work, LAT was used for the detection of Toxoplasma. The LAT is a sensitive, reliable and rapidly responsive serological test for the detection of Toxoplasma infection in sheep. The LAT showed rapid response with antibody first appearing by two to three weeks after infection (Trees et al., 1989).

This result showed that age group is an important factor. Older sheep were found to have a higher infection rate than younger ones. This result is similar to that of Caballero-Ortega et al. (2008) who found that older animals were more frequently positive and with a stronger response than young ones. In addition Natale et al. (2007), Dumeter, 
et al. (2006) indicated that ovine toxoplasmosis seroprevalence was generally increasing according to age and was significantly lower in animals younger than one year. Similar results were obtaind in the present study where the highest prevalence was found in sheep more than one year old.

This study also showed that the prevalence of Toxopasma gondii antibodies in ewes was higher than rams, this is similar to those reported in Ghana and Saudi Arabia (Van der puije et al., 2000, Sanad and ALghabban, 2007) and differs from that of Caballero-Ortega et al. (2008), who observed no differences between male and female sheep.

Finally, the results of this study confirm the presence of Toxoplasma gondii antibodies in Libyan sheep. Toxoplasma infection among animals is of great importance, because some of the infected animals play a distinct role as a source of human infection.

\section{REFERENCES}

Caballero-Ortega, H.; Palma, J.M.; García-Márquez, L.J.; GildoCárdenas, A. and Correa, D. (2008): Frequency and risk factors for toxoplasmosis in ovines of various regions of the State of Colima, Mexico. Parasitology, 135 (12):1385-9.

Dubey, J.P. and Beattie, C.P. (1988): Toxoplasmosis of animals and man.CRC Prss, Boca Raton, florida. 61-80.

Dubey, J.P. (1994): Toxoplasmosis. JAVMA, 205(11): 1593-1597.

Dumeter, A.; Ajzenberg, D.; Rozette, L.; Mercier, A. and Dardé, M. (2006): Toxoplasma gondii infection in sheep from HauteVienne, France: Seroprevalence and isolate genotyping by microsatellite analysis, Veterinary Parasitology, 142, 376-379.

Fusco, G.; Rinaldi, L.; Guarino, A.; Proroga, Y.; Pesce, A.; Giuseppina, D. and Cringoli, G. (2007): Toxoplasma gondii in sheep from the Campania region (Italy), Veterinary Parasitology, 149, 271-274.

Gusbi, A.M. (1986): Studies on Toxoplasmosis in farm animals in Libya. Transactions of the Royal society of Tropical Medicine and Hygiene, 80: 337.

Hashemi-Fesharki, R. (1996): Seroprevalence of Toxoplasma gondii in cattle, sheep and goats in Iran.Vet Parasitol. 61(1-2): 1-3.

Helmick, B.; Otter, A.; McGarry, J. and Buxton, D. (2002): Serological investigation of aborted sheep and pigs for infection by Neospora caninum. Res Vet Sci. Oct, 73(2): 187-9. 
Hoghooghi-Rad, N. and Afraa, M. (1993): Prevalence of toxoplasmosis in humans and domestic animals in Ahwaz, capital of Khoozestan Province, south-west Iran. J Trop Med Hyg. 96(3): 163-8.

Kassem, H.H. and Morsy, T.A. (1991): The prevalence of antiToxoplasma antibodies among pregnant women in Benghazi, (S.P.L.A.J.) Libya. J. Egypt. Soc. Parasitol. 21(1): 69-74.

Khader, M.A. and ELNageh, M.M. (1987): Serological survey for Toxoplasmosis in Tripoli, Libya, Trans. Royal. Soci. Trop. Med. and Hygiene, 81, 761-763.

Masala, G.; Porcu, R.; Medau, L.; Tanda, A.; Ibba, B.; Satta, G.; Tola, $S$. (2003): Survey of ovine and caprine Toxoplasmosis by IFAT and PCR assays in Sardinia. Italy, Vet. Parasitol., 117: 15-21.

Natale, A.; Porqueddu, M.; Capelli, G.; Mocci, G.; Marras, A.; Sanna Coccone, G.N.; Garippa, G. and Scala, A. (2007): Seroepidemiological update on sheep toxoplasmosis in Sardinia, Italy. Parassitologia. 49(4): 235-8.

Negash, T.; Tilahun, G.; Patton, S.P.; Prevot, F.; Dorchies, P.H. (2004): Serological survey on Toxoplasmosis in sheep and goats in Nazareth Ethiopia, Revue .Med. Vet., 155, 10, 486-487.

Nissapatorn, V.; Lee, C.; Quek, K.; Leonyg, C.; Mahmud, R. and Abdullah, K. (2004): Toxoplasmosis in HIV, AIDS patient: acurrent situation, Jpn. J. infection. Dis., 57, 160-165.

Oncel, T.; Vurali, G.; Babur, C. and Kilic, S. (2005): Detection of Toxoplasmosis gondii seropositivity in sheep in Yalova by sabin Feldman dye test and latex agglutination test, Turkiye Parazitoloji, Derngisi, 29(1):10-12.

Pita Gondim, L.F.; Barbosa, H.V.; Ribeiro Filho, C.H. and Saeki, H. (1999): Serological survey of antibodies to Toxoplasma gondii in goats, sheep, cattle and water buffaloes in Brazil, Veterinary Parasitology, 82, 273-276.

Samad, M.; Rahman, K.B. and Halder, A.K. (1993): Seroprevalence of Toxoplasma gondii in domestic ruminants in Bangladesh, Veterinary Parasitology, 47, 157-159.

Sanad, M.M. and Alghabban, A.J. (2007): Serological survey on Toxoplasmosis among slaughtered sheep and goats in Tabouk, Saudi Arabia, Egypt, Soc. Parasitol., 37(1): 329-40.

Sawadogo, P.; Hafid, J.; Bellete, B.; Tran Manh Sung, B.; Chakdi, M.; Flori, P.; Raberin, H.; Bent Hamouni, I.; Chait, A. and Dalal, 
A. (2005): Seroprevalence of Toxoplasma gondii in sheep from Marrakech. Morocco. Veterinary Parasitology, 130: 89-92.

Tenter, A.M.; Heckeroth, A.R. and Weiss, L.M. (2000): Toxoplasma gondii: from animals to humans, Int. J. Parasitol., 30: 1217-1258

Trees, A.J.; Crozier, S.J.; Buxton, D. and Blewett, D.A. (1989): Serodiagnosis of ovine toxoplasmosis: an assessment of the latex agglutination test and the value of IgM specific titres after experimental oocyst-induced infections. Res Vet Sci. 46(1): 67-72.

Van der Puije, W.N.; Bosompem, K.M.; Canacoo, E.A.; Wastling, J.M. and Akanmori, B.D. (2000): The prevalence of antitoxoplasma gondii antibodies in Ghanaian sheep and goata, Acta .Tropica., 76: 21-26.

Zaki, M. (1995): Seroprevalence of Toxoplasma gondii in domestic animals in Pakistan. J. Pak. Med. Assoc. 45(1): 4-5.

Zia-Ali, N.; Fazaeli, A.; Khoramizadeh, M.; Ajzenberg, D.; Darde, M. and Keshavarz-Valian, H. (2007): Isolation and molecular characterization of Toxoplasma gondii strains from different hosts in Iran, Parasitol. Res., 101(1): 111-5. 